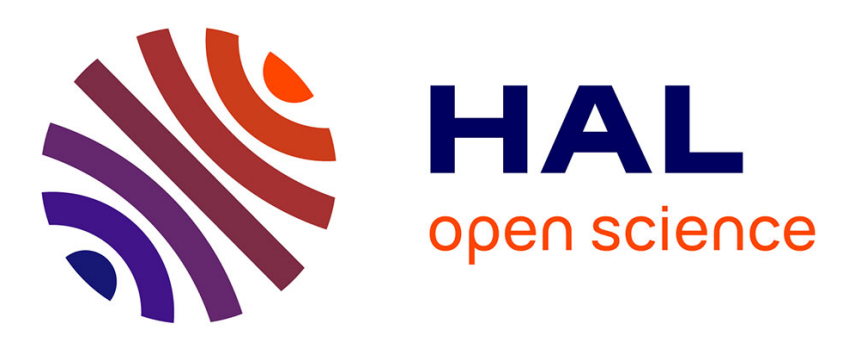

\title{
Technology transfer by CDM projects: A comparison of Brazil, China, India and Mexico
}

Antoine Dechezleprêtre, Matthieu Glachant, Yann Ménière

\section{To cite this version:}

Antoine Dechezleprêtre, Matthieu Glachant, Yann Ménière. Technology transfer by CDM projects: A comparison of Brazil, China, India and Mexico. Energy Policy, 2009, 37 (2), pp.703-711. 10.1016/j.enpol.2008.10.007 . hal-00437547

HAL Id: hal-00437547

https://hal-mines-paristech.archives-ouvertes.fr/hal-00437547

Submitted on 12 Jan 2010

HAL is a multi-disciplinary open access archive for the deposit and dissemination of scientific research documents, whether they are published or not. The documents may come from teaching and research institutions in France or abroad, or from public or private research centers.
L'archive ouverte pluridisciplinaire HAL, est destinée au dépôt et à la diffusion de documents scientifiques de niveau recherche, publiés ou non, émanant des établissements d'enseignement et de recherche français ou étrangers, des laboratoires publics ou privés. 


\title{
Technology transfer by CDM projects: a comparison of Brazil, China, India and Mexico
}

\author{
Antoine Dechezleprêtre ${ }^{a}$, Matthieu Glachant ${ }^{a *}$, Yann Ménière $^{a}$ \\ ${ }^{a}$ CERNA, École des mines ParisTech, France \\ * Corresponding author \\ CERNA, École des mines de Paris \\ 60, Boulevard Saint Michel \\ 75272 Paris Cedex 06, France \\ Tel.: + 33140519229 \\ Fax : +33140519145 \\ E-mail: glachant@ensmp.fr
}

\begin{abstract}
In a companion paper (Dechezleprêtre et al., 2008), we gave a general description of technology transfers by CDM projects and we analyzed their drivers. In this paper, we use the same data and similar econometric models to explain inter-country differences. We focus on 4 countries gathering about $75 \%$ of the CDM projects: Brazil, China, India, and Mexico. $68 \%$ of Mexican projects include an international transfer of technology. The rates are respectively $12 \%, 40 \%$ and $59 \%$ for India, Brazil and China.

Our results show that transfers to Mexico and Brazil are mainly related to the strong involvement of foreign partners and good technological capabilities. Besides a relative advantage with respect to these factors, the higher rate of international transfers in Mexico seems to be due to a sectorcomposition effect. The involvement of foreign partners is less frequent in India and China, where investment opportunities generated by fast growing economies seem to play a more important role in facilitating international technology transfers through the CDM. International transfers are also related to strong technology capabilities in China. By contrast, the lower rate of international transfer $(12 \%)$ in India may be due to a better capability to diffuse domestic technologies.
\end{abstract}




\section{Introduction}

The success of post-Kyoto climate policies will crucially hinge on the involvement of fast growing emerging countries such as China, India or Brazil. Such involvement however raises difficult policy issues that largely shape the current climate negotiations. To reduce the greenhouse gas (GHG) intensity of their growth paths, emerging countries would have to implement environmentally friendly technologies on a massive scale. Thus far, most of these technologies have been developed and used in developed countries. To catch up, developing countries must either develop the technology by their own means, or acquire it abroad - two costly options. Against this background, enhanced action on technology development and transfer was marked as one of the objectives the December 2007 Bali road map, and discussions have started in the Expert Group on Technology Transfer to find effective and acceptable mechanisms to fulfil this goal.

The Clean Development Mechanism (CDM) of the Kyoto protocol was a first attempt to address these challenges. CDM allows industrialized countries which have accepted emissions reduction targets to develop or finance projects that reduce GHG emissions in non-Annex 1 countries in exchange for emission reduction credits. Since reducing GHG emissions in a less-developed country may be cheaper than doing so domestically, it helps Annex 1 countries to achieve their emission reduction target at a lower cost. Besides saving abatement costs, the goal of the CDM is to promote sustainable development in non-Annex 1 countries (for a review on this aspect of the CDM, see Olsen, 2007). It is also considered by many as a key means to boost technology transfer and diffusion. Projects may in particular lead to international transfer if the technology used in the project is not available in the host country and has to be imported. Although international transfers are not necessarily better than the replication of domestic technology (the latter being in some cases more appropriate to match local conditions), it is of course important to analyze whether the CDM is effective in this respect. We aim to do so in this paper by comparing international technology transfers induced by the CDM in four emerging countries - namely China, India, Brazil and Mexico - which are also the main recipients of CDM projects.

The transfer of GHG mitigation technologies to developing countries is the subject of an extensive general literature (for example, Blackman, 1999; Yang, 1999; IPCC, 2000; Yang and Nordhaus 2006). Numerous case studies of successful technology transfers have also been conducted in order to assess the drivers for and barriers to technology adoption (for instance, OCDE/IEA 2001; Kathuria 2002; Ockwell et al. 2008). Ockwell et al. The literature on technology transfers through CDM is more recent but it is growing fast. A good review can be found in Scheider et al. (2008), with a detailed analysis of the CDM contribution to the alleviation of various barriers to technology transfer. Several papers use a quantitative approach. Based on a sample of 63 registered projects, De Coninck, Haake 
and van der Linden (2007) show that imported technologies originate mostly from the European Union and that the investments from industrialized countries associated with the CDM are small when compared to total foreign direct investments. Seres et al. (2007) ${ }^{1}$ and Dechezleprêtre et al. (2008) analyze technology transfers respectively in 2293 projects in the CDM pipeline and 644 registered projects. They find transfers in respectively $39 \%$ and $43 \%$ of these projects (accounting for $64 \%$ and $84 \%$ of emission reduction claims). Using regression analysis, both papers find that larger projects and projects with foreign participants involve more technology transfer. Dechezleprêtre et al. (2008) consider other variables such as the technology capabilities of recipient countries, and whether project developers are subsidiaries of Western companies, both of which have significant positive effects on transfers.

As compared to these papers, our originality is to compare different countries and to seek to identify what explains their differences. We follow the econometric approach used in Dechezleprêtre et al. (2008). We use the same data and similar econometric models to explain inter-country differences. The four countries we focus on - Brazil, China, India, and Mexico - gather about $75 \%$ of the CDM projects. We seek to highlight and to explain the national specificities of technology diffusion by the CDM, such as differences in the percentage of projects where a technology is imported from abroad. Although our main focus is on international transfers of technology, we also take into account and discuss country differences as regards the diffusion of purely domestic technology.

The remainder of this article is organized as follows. In section 2 we describe the data. Then we give descriptive statistics by country on the frequency of transfer, on the types of technology involved, etc. In Section 4, we present an econometric model which is used in Section 5 to explain inter-country differences with respect to technology transfer. We conclude in Section 6.

\section{Data issues}

\subsection{Sources}

Our data describe all the 644 projects registered as of May $1^{\text {st }}, 2007$. These projects account for an expected 888.5 million tons of $\mathrm{CO}_{2}$-equivalent $\left(\mathrm{MtCO}_{2} \mathrm{eq}\right)$ emissions reductions by the end of 2012 . We use three main information sources to describe these projects: 1) the UNEP Risoe Center CDM Pipeline database $\left.{ }^{2}, 2\right)$ the Project Design Documents, and 3) data from international institutions such as the World Bank and the World Trade Organization for country-level economic and technological variables.

For every CDM project, the UNEP Risoe Center CDM Pipeline database includes the host country, the type of technology, the estimated amount of the annual emissions reductions, the cumulative emissions reductions to the end of the Kyoto period (31 December 2012) and the countries that will

\footnotetext{
${ }^{1}$ In an extension of Haites et al. (2006).

${ }^{2}$ The database is available at http://cdmpipeline.org/
} 
buy the carbon credits generated by the project (if already available). We have also collected the registration dates of each project and the name of every country involved, on the UNFCCC website dedicated to CDM projects ${ }^{3}$.

The content of the Project Design Documents (PDD) is our main source of information. They are mandatory standardized documents of about 50 pages submitted to the Executive Board by the project developers for registration. In the PDDs, we have collected information about the technology used, whether there is a transfer or not, the type of transfer, the project implementer (name, business sector and name of parent company) and every foreign partner involved (name, location). We have also retrieved information on the role of the project partners: are they credit buyers, consulting companies, PDD consultants or equipment suppliers?

Host country characteristics, including information on GDP, trade or FDI flows have been obtained from the World Bank's World Development Indicators 2006 ${ }^{4}$. We have completed this information with economic performance indicators from the Earth Trends database of the World Resource Institute ${ }^{5}$. To proxy the technological capability of a country to import and use advanced technology, we have used the composite index Arco developed by Archibugi and Coco (2004).

\subsection{Information on technology transfers}

We define technology transfer as the import of a technology from abroad. It is important to keep in mind that this definition does not encompass all forms of technology diffusion. CDM projects may also entail technology transfers within a country, e.g; from an urban to a rural area. Unfortunately such intra-country transfers are difficult to track in PDDs, and therefore they do not lend themselves easily to statistical analysis. By contrast, international transfers can be identified and make it possible to carry out more ambitious analysis. They are also of prime interest for us since they relate directly to international negotiations on technology transfers.

The technology that is transferred may take various forms. Knowledge transfers take place if the local project developer benefits from the transfer of knowledge, know-how, information or technical assistance from a foreign partner. By contrast, an equipment transfer consists in importing equipment, such as wind turbines or gas burners, from a supplier located in a foreign country. Of course, a project can involve both a transfer of equipment and a transfer of knowledge.

We find information on transfers in the PDDs. In principle, the technology to be employed in the project activity is described in section A.4. $3^{6}$. But this is not a compulsory requirement, and no section is specifically devoted to technology transfer. Indeed, claims of technology transfer can often be found in other[s] sections such as "Description of the project activity" (A.2) or "Barrier analysis" (B.4). Section G ("Stakeholders' comments") sometimes contains interesting information on equipment suppliers. Further information on the technology employed may also be displayed in the annex. In order to get

\footnotetext{
${ }^{3}$ http://cdm.unfccc.int/Projects/index.html

4 Available online at http://devdata.worldbank.org/wdi2006

5 http://earthtrends.wri.org/

6 The Guidelines for completing the PDD available from UNFCCC indicate that "this section should include a description of how environmentally safe and sound technology, and know-how to be used, is transferred to the host Party(ies)."
} 
relevant information, we have read carefully all the PDDs ${ }^{7}$. More details and examples can be found in Dechezleprêtre et al. (2008).

How reliable is this information? There are several potential problems which we have tried to mitigate. In some PDDs, a transfer of technology may refer to the simple adoption of a new technology. If the technology provider is clearly located within the country, the project involves no international transfer; consequently our database records no international transfer for that project in that country.

Another difficulty concerns specifically the import of equipment. From a general point of view, the import of goods does not always entail a technology transfer. For instance, importing a DVD player made in China into the U.S. does not. The same is true for CDM projects which might include the import of generic devices. In this regard, we have considered that the import of equipment is associated with a technology transfer as soon as the PDD claims that it is.

It remains that PDD editors have an incentive to overstate the existence of technology transfer as it helps project registration. Accordingly, type I errors are unlikely while type II errors could be frequent even if any claim of technology transfer should be justified in the PDD $^{8}$. Therefore, descriptive statistics regarding technology transfer percentages are probably less reliable than other figures. ${ }^{9}$ This is a usual difficulty with this type of study. But one can realistically assume that this bias is randomly distributed over the PDD-writing population. Therefore, this problem probably does not damage our econometric results.

\section{Descriptive statistics by country}

In this section, we describe the international technology transfers occurring in CDM projects in Brazil, China, India and Mexico. As shown in Table 1, the share of projects involving such transfers varies greatly across countries. $68 \%$ of projects set up in Mexico involve an international technology transfer, but only $12 \%$ of projects located in India.

In most cases international transfers are not limited to the import of equipment. The transfer of both equipment and knowledge is observed in $42 \%$ of Chinese projects and $46 \%$ of Indian projects. Transfers of knowledge alone are very frequent in Brazil (23\%) and in Mexico (68\%). This is mainly due to the high number of projects taking place in the agricultural sector in these two countries.

\footnotetext{
7 For efficiency purposes, we first searched the PDDs for the words "technology", "transfer", "equipment", "supplier", "import", "manufacturer" and "training". If no information on technology transfer could be found through this search, we then read through the entire PDD.

${ }^{8}$ A type I error consists of wrongly describing a project as not involving any technology transfer. Conversely, a type II error occurs when a project is wrongly described as involving a technology transfer (when it does not).

${ }^{9}$ Haites et al. (2006) find that $33 \%$ of the projects involve transfer, compared to $43 \%$ in our data set. One possible reason is that the datasets are slightly different. Another is the procedure used in both papers for encoding technology transfer. We read the entire PDDs whereas Haites et al. (2006) only searched for the word "technology".
} 
Table 1 - International technology transfer by host country

\begin{tabular}{|l|l|l|l|l|l|}
\hline \multirow{2}{*}{ Country } & $\begin{array}{l}\text { Total } \\
\text { number } \\
\text { projects } \\
{[N]}\end{array}$ & $\begin{array}{l}\text { Number of projects involving technology } \\
\text { transfer }\end{array}$ & $\begin{array}{l}\text { Percentage } \\
\text { of technology } \\
\text { transfer }\end{array}$ \\
\cline { 3 - 6 } & $\begin{array}{l}\text { Equipment } \\
\text { only } \\
{[E]}\end{array}$ & $\begin{array}{l}\text { Knowledge } \\
\text { only } \\
{[K]}\end{array}$ & $\begin{array}{l}\text { Equipment }+ \\
\text { Knowledge } \\
{[B]}\end{array}$ & {$[(E+K+B) / N]$} \\
\hline India & 225 & 10 & 5 & 13 & $12 \%$ \\
Brazil & 99 & 8 & 23 & 9 & $40 \%$ \\
Mexico & 78 & 4 & 45 & 4 & $68 \%$ \\
China & 71 & 11 & 1 & 30 & $59 \%$ \\
\hline Total & 473 & 33 & 74 & 56 & $34 \%$ \\
\hline
\end{tabular}

Table 2 gives additional information on the projects. In average, Chinese projects are much larger. This is essentially due to the presence of 7 huge projects of HFC-23 destruction. The percentage of projects which are located in the subsidiary of Annex 1 countries' companies is interesting as one might expect more transfers in these projects. In this regard, China and India sharply differ from Brazil and Mexico, where such projects are much more frequent. Finally, the presence of a foreign credit buyer may also facilitate transfer. They are involved in most projects in China and Mexico, but only in $36 \%$ of the Indian projects.

Table 2 - Project characteristics by host country

\begin{tabular}{|l|l|l|l|l|}
\hline Variables & \multicolumn{1}{|c|}{ China } & India & Brazil & Mexico \\
\hline Average size $\left(\mathrm{ktCO}_{2}\right.$ eq/year) & 816.7 & 85.2 & 160.0 & 76.5 \\
Median size $\left(\mathrm{ktCO}_{2}\right.$ eq/year) & 110 & 26 & 42 & 17 \\
$\begin{array}{l}\text { Projects implemented in a subsidiary of } \\
\text { annex I company }\end{array}$ & $0 \%$ & $3 \%$ & $28 \%$ & $56 \%$ \\
Projects with a foreign credit buyer & $89 \%$ & $36 \%$ & $52 \%$ & $97 \%$ \\
\hline
\end{tabular}

We now give more specific information on the types of technology that are transferred in each country.

\subsection{Brazil}

CDM projects in Brazil belong to two main types: renewable energy production and biogas recovery in breeding farms and landfills (see table 3). Renewable energy projects mostly consist of hydro power and biomass energy production. The latter are usually set up in sugar mills where bagasse - a residue from sugarcane processing - is used as a feedstock for cogeneration of heat and electricity. These power plants rely on direct-fired systems that are very similar to usual fossil-fuel fired power plants. 
Thus there is no need to import technologies. Hydropower is also common in Brazil as it supplies more than $80 \%$ of electricity in this country. A few wind energy projects use turbines supplied by Enercon, Germany.

The second most popular type of CDM projects in Brazil is biogas recovery. They generally entail technology transfer. In particular, projects in breeding farms mitigating biogas resulting from the decomposition process of animal effluents present interesting channels of technology diffusion. $85 \%$ of these projects benefit from technology transfers from AgCert. This Irish consulting company provides farmers with turnkey solutions, including training sessions on how to operate the technology. It also operates in Mexico as will see below.

However, in terms of emission reductions, the most important projects concern landfill gas capture and $\mathrm{N}_{2} \mathrm{O}$ destruction. Projects in landfills mainly use foreign technology. In particular, several projects set up in subsidiaries of French companies Veolia Environnement and Suez benefited from internal transfers of know-how.

As for the $\mathrm{N}_{2} \mathrm{O}$ destruction project, there is only one huge project in a chemical facility producing adipic acid. It amounts for nearly 6 million tons of annual $\mathrm{CO}_{2}$ eq reductions, i.e. $38 \%$ of the annual reductions in Brazil by CDM projects. The plant is owned by Rhodia and the Brazilian facility benefits from transfers of know-how from the facility of Chalampé located in France.

Table 3 - Main project types and international technology transfers in Brazil

\begin{tabular}{|c|c|c|c|c|}
\hline Type of technology & $\begin{array}{c}\text { Number of } \\
\text { projects }\end{array}$ & $\begin{array}{c}\text { Percentage of } \\
\text { projects involving } \\
\text { intern. technology } \\
\text { transfer }\end{array}$ & $\begin{array}{c}\text { Average } \\
\text { project size } \\
\text { (annual } \\
\left.\mathrm{ktCO}_{2} \mathrm{eq}\right)\end{array}$ & $\begin{array}{c}\text { Total annual } \\
\text { reductions } \\
\text { (ktCO }\end{array}$ \\
\hline $\begin{array}{c}\text { Biog) } \\
\text { Biogas recovery in agriculture } \\
\text { (breeding farms) }\end{array}$ & 34 & $9 \%$ & 51 & 1747 \\
Hydro power & 19 & $90 \%$ & 74 & 1477 \\
Landfill gas recovery & 13 & $11 \%$ & 45 & 852 \\
$\mathrm{~N}_{2}$ O destruction & 1 & $100 \%$ & 402 & 5225 \\
Wind power & 4 & $75 \%$ & 5961 & 5961 \\
Energy efficiency (industry) & 2 & $0 \%$ & 42 & 169 \\
Fossil fuel switch & 5 & $20 \%$ & 20 & 93 \\
Fugitive gas recovery & 1 & $100 \%$ & 220 & 99 \\
\hline
\end{tabular}

\subsection{China}

China also implements many renewable energy projects as shown in Table 4. The country can rely on local technologies for hydro power and biomass energy projects but depends upon imported turbines for wind power projects. The main suppliers of wind turbines are Gamesa Eolica (Spain) with 12 projects and Vestas (Denmark) with 8 projects. Notably, 55\% of the wind projects registered in April 2007 use turbines manufactured by the local firm Goldwind. Imported turbines have higher capacities on average than locally produced turbines (1.11 MW against $750 \mathrm{~kW}$ ). 
China is the leading country for HFC-23 destruction projects. These 7 projects represent $80 \%$ of the annual reductions in China and they always entail a technology transfer. The French company Vichem provides the HFC destruction technology of 4 out of 7 projects. The rest is supplied by Japanese corporations.

As landfill gas capture and flaring is new in China, local CDM developers have frequently cooperated with foreign suppliers such as Waste Management New Zealand or Energi Gruppend Jylland Denmark. This leads to an $85 \%$ rate of technology transfer in this area.

Table 4 - Main project types and international technology transfers in China

\begin{tabular}{|c|c|c|c|c|}
\hline Type of technology & $\begin{array}{l}\text { Number of } \\
\text { projects }\end{array}$ & $\begin{array}{l}\text { Percentage } \\
\text { projects involving } \\
\text { intern. technology } \\
\text { transfer }\end{array}$ & $\begin{array}{l}\text { Average } \\
\text { project size } \\
\text { (annual } \\
\left.\mathrm{ktCO}_{2} \mathrm{eq}\right)\end{array}$ & $\begin{array}{l}\text { Total annua } \\
\text { reductions } \\
\left(\mathrm{ktCO}_{2} \mathrm{eq}\right)\end{array}$ \\
\hline Wind power & 34 & $74 \%$ & 112 & 3807 \\
\hline Hydro power & 13 & $0 \%$ & 104 & 1349 \\
\hline HFC decomposition & 7 & $100 \%$ & 6743 & 47200 \\
\hline Biomass energy & 5 & $20 \%$ & 160 & 802 \\
\hline Methane destruction & 3 & $66 \%$ & 462 & 1387 \\
\hline Energy efficiency (industry) & 3 & $66 \%$ & 804 & 2413 \\
\hline Landfill gas recovery & 4 & $100 \%$ & 163 & 652 \\
\hline $\mathrm{N}_{2} \mathrm{O}$ destruction & 1 & $100 \%$ & 350 & 350 \\
\hline Reforestation & 1 & $0 \%$ & 26 & 26 \\
\hline
\end{tabular}

\subsection{India}

India is the main host country for CDM projects but as mentioned above, international technology transfer is very limited. However this does not imply that there is no technology diffusion. As in China, biomass energy and hydro power projects rely on local technologies (see Table 5). But, contrary to China, most wind power projects use equipment produced by local manufacturers (mainly Suzlon and Enercon India).

Energy efficiency measures in industry - power generation from waste heat recovery or reduction of steam consumption - are usually designed locally. However, technology partnerships have been set up in a few projects. For example, Technovacuum Russia has supplied a technology aiming at reducing steam consumption in a petroleum refinery and Giammarco-Vetrcoke Italy has implemented a solution to reduce energy consumption at an ammonia plant. The technology used in the three HFC destruction projects also comes from Europe (Ineos UK, SGL Acotec and Caloric Anlagenbau Germany).

Interestingly, the unique solar power project in India has been developed through a partnership between a German physicist Wolfgang Scheffler - who has invented the so-called Scheffler reflectors for solar cooking - and Indian institutions. 
Table 5 - Main project types and international technology transfers in India

\begin{tabular}{|c|c|c|c|c|}
\hline Type of technology & $\begin{array}{c}\text { Number of } \\
\text { projects }\end{array}$ & $\begin{array}{c}\text { Percentage of } \\
\text { projects involving } \\
\text { intern. technology } \\
\text { transfer }\end{array}$ & $\begin{array}{c}\text { Average } \\
\text { project size } \\
\text { (annual } \\
\left.\mathrm{ktCO}_{2} \mathrm{eq}\right)\end{array}$ & $\begin{array}{c}\text { Total annual } \\
\text { reductions } \\
\text { (ktCO }\end{array}$ \\
\hline Biomass energy & 78 & $8 \%$ & 38 & 2926 \\
Energy efficiency (industry) & 54 & $17 \%$ & 85 & 4595 \\
Hydro power & 30 & $0 \%$ & 34 & 1030 \\
Wind power & 26 & $23 \%$ & 29 & 763 \\
Reduction of the share of & 13 & $0 \%$ & 119 & 1544 \\
clinker in cement production & 7 & $0 \%$ & 32 & 224 \\
Biogas (other) & 3 & $100 \%$ & 2589 & 7766 \\
HFC decomposition & 4 & $25 \%$ & 43 & 171 \\
Fossil fuel switch & 1 & $100 \%$ & 3 & 3 \\
Energy efficiency (services) & 6 & $0 \%$ & 6 & 38 \\
Energy efficiency (supply side) & 1 & $100 \%$ & 1 & 1 \\
Solar power & 1 & \multicolumn{2}{|c|}{}
\end{tabular}

\subsection{Mexico}

Mexico is very specific: almost $90 \%$ of CDM projects concern biogas recovery in breeding farms (Table 6). AgCert - the Irish company previously evoked for Brazil - has initiated 41 projects involving technology transfers through training of local staff. Granjas Carroll Mexico - the largest commercial pig producer in Mexico - has developed 24 projects with the help of the EcoSecurities (though no technology transfer is claimed in this case). The CDM has clearly enhanced the diffusion of biogas mitigation among Mexican pork producers.

Among the other Mexican projects with technology transfer, there is one large HFC project, which yields more annual emission reductions than the 69 biogas recovery projects altogether, and three wind power projects using turbines supplied by Gamesa Eolica. Two landfill gas projects have been developed through a partnership between EcoMethane and technology providers from UK, Biogas Technology Ltd and ENER*G.

Table 6 - Main project types and international technology transfers in Mexico

\begin{tabular}{|c|c|c|c|c|}
\hline Type of technology & $\begin{array}{c}\text { Number } \\
\text { of } \\
\text { projects }\end{array}$ & $\begin{array}{c}\text { Percentage of } \\
\text { projects involving } \\
\text { intern. technology } \\
\text { transfer }\end{array}$ & $\begin{array}{c}\text { Average } \\
\text { project size } \\
\text { (annual } \\
\left.\mathrm{ktCO}_{2} \mathrm{eq}\right)\end{array}$ & $\begin{array}{c}\text { Total annual } \\
\text { reductions } \\
\text { (ktCO }\end{array}$ \\
\hline $\begin{array}{c}\text { Biogas }) \\
\text { (brecovery in agriculture }\end{array}$ & 69 & $65 \%$ & 31 & 2146 \\
HFC decomposition & 1 & $100 \%$ & 2155 & 2155 \\
Hydro power & 2 & $50 \%$ & 43 & 87 \\
Landfill gas & 2 & $100 \%$ & 186 & 373 \\
Wind power & 3 & $100 \%$ & 400 & 1201 \\
Biogas (other) & 1 & $100 \%$ & 4 & 4 \\
\hline
\end{tabular}




\section{Econometric model}

In the previous section, we have presented statistics describing inter-country differences in international technology transfers by CDM. These statistics do not help us to understand what drives these differences. For instance, $59 \%$ of the Chinese projects involve an international transfer while the percentage is only $12 \%$ in India. Why is it so? Is it because the technological capability of India is less than that of China or, by contrast, because India can rely on local technology? Is it due to sector composition effect - Indian projects may take place in economic sectors where a transfer is less likely? Is it due to project characteristics? In this section, we present an econometric model which we will use in the next section to answer these questions. Econometric analysis allows us to determine the specific effect of each variable on the likelihood that a project involves international technology transfer, all other factors being held constant.The model is very close to the models presented in Dechezleprêtre et al. (2008).

\subsection{Model specification}

Let TECH_TRANSFER denote a binary variable equal to 1 if a project involves a technology transfer (regardless of the nature of this transfer), and to 0 otherwise. To examine the relationship between TECH_TRANSFER and a set of explanatory variables, the following logit equation is estimated:

$$
\operatorname{Pr}\left(T E C H \_T R A N S F E R=1\right)=\frac{e^{\Omega}}{1+e^{\Omega}}
$$

with:

$$
\begin{aligned}
\Omega & =\alpha_{0}+\alpha_{1}(\text { LOGSIZE })+\alpha_{2}(\text { CREDIT_BUYER })+\alpha_{3}(\text { SUBSIDIARY }) \\
& +\alpha_{4}(\text { SIMILAR_PROJECTS })+\alpha_{5}(\text { TRADE })+\alpha_{6}(\text { FDI_INFLOWS }) \\
& +\alpha_{6}(\text { GDP_GROWTH })+\alpha_{7}\left(L O G_{-} \text {POPULATION }\right)+\alpha_{8}\left(G D P \_ \text {PERCAPITA }\right) \\
& +\alpha_{9}(\text { CARBON_INTENSITY })+\alpha_{10}(\text { TECH_CAPACITY }) \\
& +\alpha_{n}\left(\text { SECTOR }_{n}\right)+\alpha_{o}(\text { COUNTRY })_{o}+\varepsilon
\end{aligned}
$$

$\alpha_{\mathrm{i}}$ is a vector of coefficients to be estimated and $\varepsilon$ is a random term identically independently distributed following a Gumbel extreme distribution. We use a set of regression variables at the project and country levels that are likely to influence the probability that a CDM project involves some international transfer of technology.

According to Schneider et al. (2008), technology transfers through CDM projects are hindered by four types of barriers pertaining respectively to their commercial viability; the lack of information on the existence and functioning of the CDM, or on available technologies; a lack of access to capital; and 
the institutional framework in the host country. Following their analysis, we identify three variables at the project level that may help to alleviate the first three barriers.

We use the log of the project size (LOGSIZE), as measured by its annual emissions reduction, as an indicator of the commercial viability of CDM projects. ${ }^{10}$ As a general rule, the CDM registration process entails large transaction costs that are fixed and therefore represent a strong impediment to small scale projects (Michaelowa et al., 2003). Similarly, upfront investment costs are higher when technology is imported from industrialized countries (Schneider et al., 2008). This is especially true when the technology is at an early commercialization stage, which it is often the case with environmentally sound technologies (Wilkins, 2002). Consequently, we can expect projects involving technology transfer to be more viable if they are large.

The two other project variables relate to the access to information and capital. SUBSIDIARY is a dummy variable indicating whether the project is implemented in the subsidiary of a company located in an Annex 1 country. The involvement of a parent company can facilitate technology transfers in many ways. It may help manage the CDM registration, provide expertise at the technology level, or provide an easier access to capital.

Financial barriers can also be alleviated thanks to the participation of one or more credit buyers that are not parent companies but rather carbon founds. Before the project developer can sell the credits, the UNFCCC must first certify, issue and register the emission reduction and this administrative process takes time. Selling credits through a forward contract can be of great help. It reduces the risk surrounding the investments by adding a guaranteed revenue stream. One can assume that credit buyers also give advice and bring expertise that may ease technology transfer. We therefore define CREDIT_BUYER as a dummy variable indicating the participation of one or more credit buyers in the project, and expect a positive effect of this variable on the probability of international transfer.

The remaining variables characterize the capability of the host country to attract international technology transfers. We include the country size (LOG_POPULATION), the per capita GDP (GDP_PERCAPITA) and the carbon intensity of the economy (CO2_INTENSITY) as usual control variables $^{11}$. Although they are likely to affect positively the number of opportunities to undertake CDM projects, it is not obvious how they could influence the probability that those projects involve international technology transfers. By contrast, we can expect the variable GDP_GROWTH to have a positive impact on such transfers. Indeed a fast growth hinges on sustained investments which offer more opportunities for implementing new technologies through CDM projects.

Empirical evidence indicates that the adoption of a new technology is strongly associated with human capital, supporting infrastructure and research and development activities (Blackman 1997). In order to measure this technological capability (TECH_CAPABILITY), we use the ArCo technology index

\footnotetext{
${ }^{10}$ Using the logarithm of the size ensures that the few very large HFC projects do not have a disproportionate influence on the results.

${ }^{11}$ Per capita GDP and population are similarly used as control variables in previous works (see for instance Haites et al., 2006 and Seres, 2007). We added the carbon intensity of the economy as a control variable following several requests to do so by readers of previous versions of this work. As could be expected, we find no significant effect of this control variable.
} 
developed by Archibugi and Coco (2004). This composite indicator captures three aspects determining technological capabilities: the creation of technology (number of patents and number of scientific articles), the technological infrastructures (internet penetration, telephone penetration and electricity consumption) and the development of human skills (percentage of tertiary science and engineering enrolment, mean years of schooling and literacy rate). It must be noticed that the technological capability, although favoring international technology transfers at a macroeconomic level, may also imply that the technology required for CDM projects are available locally. To take this possibility into account, we add as a country variable the number of other CDM projects using the same technology within the host country (SIMILAR_PROJECTS). Of course we can expect that international technology transfers are less likely when similar projects are carried out in the same country.

There is also strong empirical evidence that international trade and Foreign Direct Investments (FDI) promote the transfer of technology across countries (Coe et al. 1997). A country openness to global trade can indeed alleviate barriers pertaining to access to information and to technology. It may also denote a favorable institutional environment. Accordingly, we use the variable TRADE which is the ratio of the sum of exports and imports of merchandise on GDP and FDI_INFLOWS which is the level of incoming FDI in the host country.

Finally, SECTORi and COUNTRYi are vectors of sector dummies and country dummies, respectively. They control for sector- and country-specific characteristics that are not captured by the other variables.

\subsection{Estimation results}

Results are displayed in Table 7. The overall quality of the estimation is reasonably good. The McFadden pseudo R-squared is 0.36 and the model correctly predicts $80 \%$ of the observed outcomes. The coefficients exhibit the expected signs.

We will be very quick on the comments of these results as this was the prime goal of the companion paper (Dechezlepretre et al., 2008). Technology transfer increases with the size of the project (LOGSIZE). The participation of one or more credit buyers in the project (CREDIT_BUYER variable) also increases the likelihood that the project involves technology transfer. Marginal calculations show that a project with a credit buyer has a $16 \%$ higher probability of involving a technology transfer.

Being the subsidiary of a company from an Annex 1 country (as indicated by the dummy variable SUBSIDIARY) clearly favors the transfer of technology. The coefficient is highly significant and much larger than that of CREDIT_BUYER. In marginal terms, the transfer likeliness of a project located in the subsidiary of an Annex 1 company is $50 \%$ higher.

Turning next to country variables, it is worth noting that the average annual rate of GDP growth from 2000 to 2004 (GDP_GROWTH) has a very high impact on the likeliness of technology transfer: one additional percentage point of average GDP growth raises transfer likeliness by $19 \%$. The variables LOG_POPULATION , GDP_PERCAPITA and CO2_INTENSITY have no significant effects in the regression. 
As expected, trade openness (TRADE) reinforces the likelihood of technology transfer. In contrast, the share of FDI inflows in GDP has a negative impact on transfer. This may be due to the fact that capital links are already captured by the variable SUBSIDIARY. National technological capabilities (TECH_CAPABILITY) have a positive and significant impact on transfer likeliness, while the number of other CDM projects using the same technology within the host country (SIMILAR_PROJECTS) lowers the probability of transfer.

Table 7 - Regression results of model explaining TECH_TRANSFER

\begin{tabular}{|c|c|}
\hline Dependant variables & Coefficients \\
\hline LOGSIZE & $0.2806^{* * *}(0.0843)$ \\
\hline CREDIT_BUYER & $0.5050^{* *}(0.2509)$ \\
\hline SUBSIDIARY & $2.3511^{* * *}(0.3579)$ \\
\hline SIMILAR_PROJECTS & $-0.4103^{* * *}(0.1206)$ \\
\hline TRADE & $0.0090^{*}(0.0057)$ \\
\hline FDI_INFLOWS & $-0.2674^{*}(0.1363)$ \\
\hline GDP_GROWTH & $0.6882^{* * *}(0.2225)$ \\
\hline GDP_PERCAPITA & $-0.0001(0.0001)$ \\
\hline LOG_POPULATION & $-0.2566(0.2641)$ \\
\hline CARBON_INTENSITY & $0.0002(0.0003)$ \\
\hline TECH_CAPABILITY & $0.0722^{*}(0.0400)$ \\
\hline SECTOR & - \\
\hline COUNTRY & - \\
\hline Nb of observations & 643 \\
\hline Pseudo-R2 & 0.36 \\
\hline Percentage of correct predictions & $79.8 \%$ \\
\hline
\end{tabular}

Notes: Standard errors in parentheses; * denotes significance at $10 \%$ level, ${ }^{* *}$ denotes significance at $5 \%$ level, and ${ }^{* * *}$ denotes significance at $1 \%$ level.

\section{Country comparison}

In this section, we use the econometric model presented in section 2 in order to analyze the impact of the explanatory variables on the overall rate of technology transfer in the different host countries. The discussion about the sign of the coefficients does not yield information about the size of the effects of the explanatory variables. In order to compare these effects across countries, we draw Figure 1 using the model's results. Figure 1 is based on the following calculation. Let $\bar{X}_{i}$ be the average value of the variable $x_{i}$ in a sample of projects and let $\beta_{i}$ denote the value of its coefficient. Then, the product $\beta_{i} \bar{X}_{i}$ represents the average impact of $x_{i}$ on the linear predictor $\Omega$ of Equation (1). Calculating the value of $\beta_{i} \bar{x}_{i}$ for every variable allows setting the average weight of each variable against the 
decision to transfer technology. Figure 1 represents these weights for the different countries. Using the same metric, each bar measures the impact of the variable on an average CDM project in each country. Finally, we only represent statistically significant variables.

Figure 1 - Comparative impacts of the explanatory variables for the different countries

CHINA

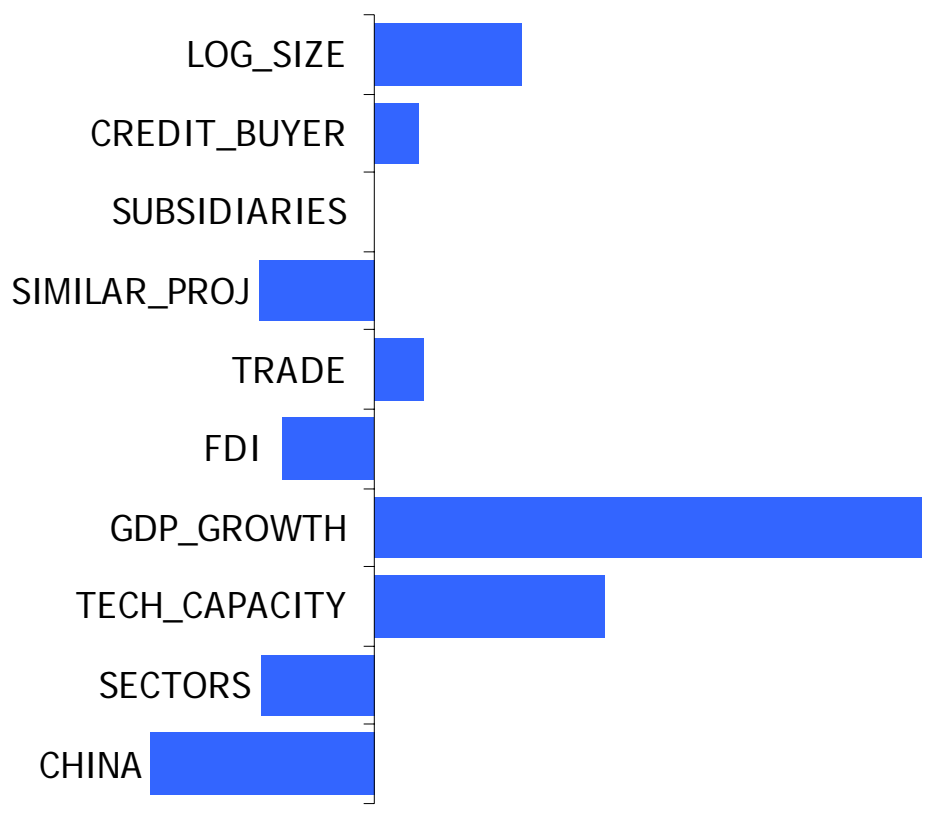

BRAZIL

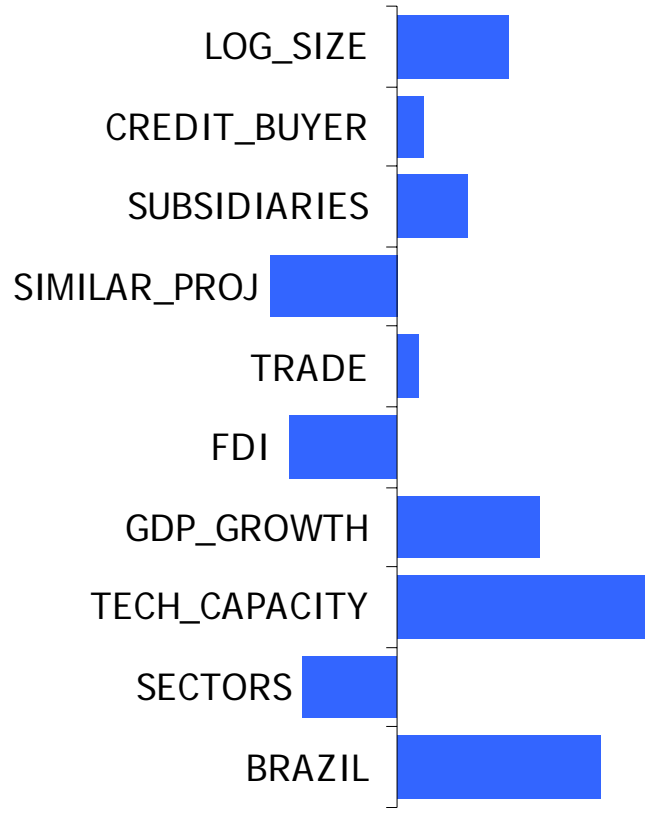

MEXICO

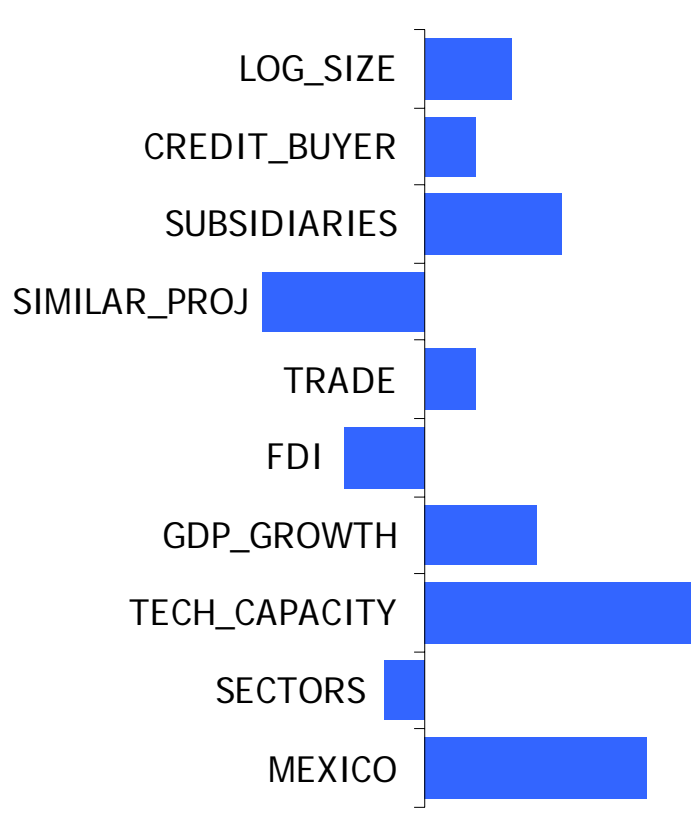

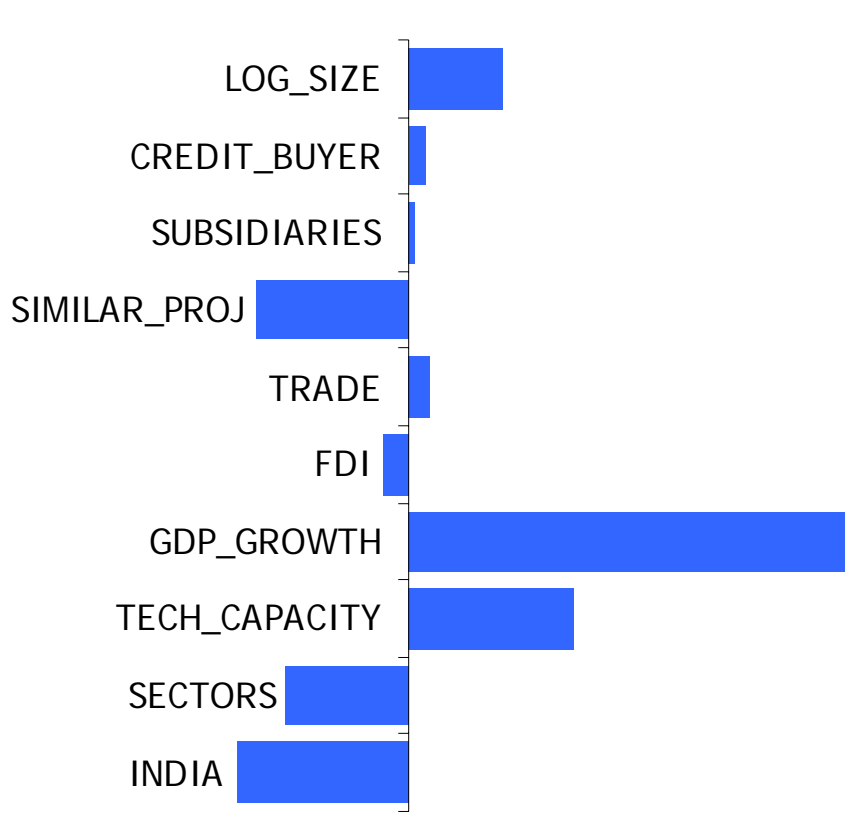


Let us use Figure 1 to compare the different countries. Consider first the effect of the project variables in Figure 1. The stronger impact of PROJECT_SIZE in China is clearly due to its large HFC projects. The two other variables, namely CREDIT_BUYER and SUBSIDIARY, denote important differences in countries' capacities to attract foreign partnerships. China and Mexico have clearly benefited from the involvement of foreign credit buyers. The advantage of Mexico is even stronger as regards foreign subsidiaries, for which Brazil is also well positioned. In contrast, India performs poorly with respect to both variables.

Turning next to country variables, the strong effect of GDP_GROWTH clearly indicates that international technology transfers are more likely in fast growing economies. Although all countries have substantial growth rates, the very fast economic growth in India and in China seem to be decisive factors in their abilities to generate projects involving technology transfers.

International technology transfers are also strongly correlated to national technology capabilities (TECH_CAPACITY). Beside a small lag in the case of India, all countries benefit in equal proportions from attractive technological capabilities. One must however balance this effect with the impact of the variable SIMILAR_PROJECTS which denotes the number of other CDM projects using the same technology within the host country. Local availability of technologies has comparable negative impacts on the likelihood of technology transfers in each country. It mitigates the positive effect of TECHCAPACITY, without suppressing it entirely. Again, the net impact is the lowest in India, which suggest that India has been particularly successful in relying on domestic technology capabilities to diffuse carbon mitigation technology through the CDM.

Sector dummies are interesting in that they reflect the sector-composition effect. Figure 1 suggests that inter-country differences are not that much influenced by this. The exception is Mexico. One possible explanation is that this country gets very specialized in biogas recovery in breeding farms which frequently entail technology transfer.

Finally, the country dummies - BRAZIL, CHINA, INDIA and MEXICO - capture factors that are not taken into account by the other country-level variables (TRADE, FDI, GDP_GROWTH and TECH_CAPACITY). They may reflect administrative peculiarities - difference in intellectual property regimes, etc.- which are not described in the database. Figure 1 shows that these unobserved factors play a strong role in explaining country differences. Although, by nature, these effects are difficult to interpret, it is likely that the national policies with respect to CDM play an important role. China has for instance been slow in setting up a Designated National Authority (DNA) to help setting up CDM projects. In contrast, Mexico and Brazil seem to benefit of more proactive policies vis-à-vis CDM projects $^{12}$.

We can now complete the discussion by relating these results with each country's performance in terms of technology transfers. Comparing the countries in Figure 1 suggests two different types of country profiles, namely Mexico and Brazil on the one hand, and China and India on the other hand.

\footnotetext{
${ }^{12}$ Remember that every host country must give its approval to CDM projects through its DNA. Interestingly, the Brazilian Designated National Authority (DNA) is hosted by the Ministry of Science \& Technology, while in the great majority of cases, the DNA is hosted by the Ministry of Environment or by some national environmental protection agency.
} 
The relative success of Mexico (where the transfer rate is $68 \%$ ) in attracting foreign technology when compared to other countries is mainly due a sector-composition effect (in particular, there are many projects of biogas recovery in breeding farms, a sector where transfers prevails) combined with good technological capabilities and a strong involvement of parent companies in Mexican subsidiaries. Brazil has a similar profile but in lesser proportions. The effect of GDP_GROWTH is slightly stronger than in Mexico, while the positive impact of sector composition, foreign subsidiaries and technological capabilities is weaker.

The profiles of India and China are quite different. Indeed neither of them has experienced a strong involvement of foreign partners. The transfer rate of $59 \%$ in China is mostly explained by the dynamism of its economy (GDP_GROWTH), combined with good technological capabilities. In comparison with China, the lower rate of international technology transfers $(12 \%)$ in India can be explained by a (relative) smaller advantage in terms of growth rates and technological capabilities, but also by a stronger propensity to rely on domestic capabilities to diffuse technology through the CDM.

\section{Conclusion}

We have described the international transfers of GHG mitigation technologies induced by the Clean Development Mechanism in Brazil, China, India and Mexico using a dataset including 644 CDM projects registered until May 2007.

Our analysis shows very large differences across countries. The percentage of projects where an international technology transfer takes place ranges from $12 \%$ in India to $68 \%$ in Mexico. Moreover, very different technologies are concerned. In Brazil and Mexico, projects recovering biogas in breeding farms represent an important share of the overall transfer. In China, Mexico and Brazil, the import of wind turbines is widespread whereas India mainly relies on local suppliers. Nevertheless, some technologies are imported whatever the country. This is true for HFC or $\mathrm{N}_{2} \mathrm{O}$ destruction technologies used in very large projects in the chemical industry. This is also the case of landfill gas capture and flaring.

Note that a high transfer rate does not mean that the country performs better than others. Consider the example of Indian wind power projects. India would seem to perform badly in this area since transfer frequency is low (23\%) as compared to others (between $75 \%$ and $100 \%$ ). But it is so because India is in fact more advanced in this area and has leading domestic producers like Suzlon.

We also develop an econometric analysis to investigate what drives these transfers. Our results highlight various patterns of technology diffusion. Transfers to Mexico (68\% of CDM project) and Brazil $(40 \%)$ are related to the same factors, namely the strong involvement of foreign partners and good technological capabilities. The high Mexican rate seems to be due to a relative advantage against Brazil with respect to these factors. Mexico moreover benefits from a sector-composition effect: many Mexican projects concern biogas recovery in breeding farms, a sector where transfers prevail.

The pattern of technology diffusion is quite different in China (59\%) and India (12\%). The involvement of foreign partners is less frequent, and international transfers seem rather related to the investment opportunities generated by fast growing economies. Our results suggest that technological capabilities 
may play different roles in both countries. Strong technology capabilities are positively correlated with international transfers in China. By contrast, the technology capabilities of India seem to be rather geared towards the replication of CDM projects involving domestic technologies only.

What are the policy lessons of this analysis? Excluding macro variables like GDP growth, the results stress the importance of project partnerships: promoting projects in subsidiaries of Annex 1 countries' companies and involving a credit buyer in the project clearly alleviate barriers to international transfers. Our results also highlight the importance of capacity building as a means to accelerate technology diffusion. A strong technology capability facilitates the import of foreign technology, but it is also a source of domestic technologies to be diffused locally. Depending on which aspect is emphasized, it may thus be leveraged for very different patterns of technology diffusion. 


\begin{tabular}{|c|c|c|c|c|c|c|c|c|}
\hline \multirow{3}{*}{ Type of technology } & \multicolumn{8}{|c|}{ Total number of projects (and projects involving transfer) } \\
\hline & \multicolumn{2}{|l|}{ Brazil } & \multicolumn{2}{|l|}{ China } & \multicolumn{2}{|l|}{ India } & \multicolumn{2}{|c|}{ Mexico } \\
\hline & Total & w/ TT & Total & $\mathrm{w} / \mathrm{TT}$ & Total & $\mathrm{w} / \mathrm{TT}$ & Total & w/ TT \\
\hline Biogas recovery (other) & & & & & 7 & 0 & 1 & 1 \\
\hline $\begin{array}{l}\text { Biogas recovery in agriculture } \\
\text { (breeding farms) }\end{array}$ & 20 & 18 & & & & & 69 & 45 \\
\hline Biomass energy & 34 & 3 & 5 & 1 & 78 & 6 & & \\
\hline Energy efficiency / supply side & & & & & 6 & 0 & & \\
\hline Energy efficiency measures in & 2 & 0 & 3 & 2 & 54 & 9 & & \\
\hline Energy efficiency measures in & & & & & 1 & 1 & & \\
\hline $\begin{array}{l}\text { the services sector } \\
\text { Fossil fuel switch }\end{array}$ & 5 & 1 & & & 4 & 1 & & \\
\hline HFC decomposition & & & 7 & 7 & 3 & 3 & 1 & 1 \\
\hline Hydro power & 19 & 2 & 13 & 0 & 30 & 0 & 2 & 1 \\
\hline Landfill gas recovery & 13 & 11 & 4 & 4 & 2 & 1 & 2 & 2 \\
\hline $\mathrm{N}_{2} \mathrm{O}$ destruction & 1 & 1 & 1 & 1 & & & & \\
\hline $\begin{array}{l}\text { Power generation from coal } \\
\text { mine methane }\end{array}$ & & & 3 & 2 & & & & \\
\hline Recovery of fugitive gas & 1 & 1 & & & & & & \\
\hline $\begin{array}{l}\text { Reduction of the share of } \\
\text { clinker in cement production }\end{array}$ & & & & & 13 & 0 & & \\
\hline Reforestation & & & 1 & 0 & & & & \\
\hline Solar power & & & & & 1 & 1 & & \\
\hline Wind power & 4 & 3 & 34 & 25 & 26 & 6 & 3 & 3 \\
\hline TOTAL & 99 & & 71 & & 225 & & 78 & \\
\hline
\end{tabular}




\section{References}

Archibugi, D., Coco, A., 2004. A new indicator of technological capabilities for developed and developing countries (ArCo), World Development 32 (4), 629-654.

Blackman A., 1999. The Economics of technology diffusion: implications for climate policy in developing countries, Discussion Paper 99-42, Resources For the Future, Washington DC.

Coe, D.T., Helpman, E., Hoffmaister, A.W., 1997. North-South R\&D spillovers, The Economic Journal 107 (440), 131-149.

De Coninck, H., Haake, F., van der Linden, N., 2007 "Technology transfer in the Clean Development Mechanism," Climate Policy, 7.

Dechezleprêtre, A., Glachant, M., Ménière, Y., 2008. The Clean Development Mechanism and the international diffusion of technologies: An empirical study, Energy Policy (in press)

Haites, E., Duan, M., Seres, S., 2006. Technology Transfer by CDM projects, Climate Policy, 6(3), 327-344.

IPCC, 2000. Methodological and Technological Issues in Technology Transfer. A Special Report of Working Group III of the Intergovernmental Panel on Climate Change. Cambridge University Press, Cambridge.

Kathuria, 2002. "Technology for GHG Reduction: A Framework with Application to India," Technological Forecasting and Social Change, 69: 405-430.

Maskus, K. E., 2004. Encouraging international technology transfer, UNCTAD/ICTSD Issue Paper, Geneva.

Michaelowa, A., Stronzik, M., Eckermann, F., Hunt, A., 2003 "Transaction Costs of the Kyoto Mechanisms," Climate Policy, 3.

Ockwell D. G., Watson J., MacKerron G., Pal P., Yamin F., 2008. "Key policy considerations for facilitating low carbon technology transfer to developing countries," Climate Policy, in press.

OECD/IEA, 2001. Technology without Border: Case studies in successful technology transfer, OECD/IEA, Paris 
Olsen, K.H., 2007. "The Clean Development Mechanism's Contribution to Sustainable Development: a Review of the Literature" RISO Working Paper.

Schneider, M., Holzer, A., Hoffmann, V.H., 2008 "Understanding the CDM's Contribution to Technology Transfer," Energy Policy, 36.

Seres, S., 2007 "Analysis of Technology Transfer in CDM Projects," prepared for UNFCCC Registration \& Issuance Unit CDM/SDM.

Train, K.E., 2003. Discrete Choice Methods with Simulation. Cambridge University Press, New York.

Wilkins, G., 2002 "Technology Transfer for Renewable Energy Overcoming Barriers in Developing Countries," Earthscan, London.

Yang, Z., 1999. Should the north make unilateral technology transfers to the south? North-South cooperation and conflicts in responses to global climate change, Resource and Energy Economics 21, $67-87$. 